
кандидат філологічних наук, доцент

Яременко Н. В. кандидат філологічних наук, доцент КПІ ДВНЗ «Криворізький національний університет»

\title{
РЕЦЕПЦІЯ ІДЕЇ ХРИСТИЯНСТВА В ЛІТЕРАТУРІ РАННЬОГО СЕРЕДНЬОВІЧЧЯ
}

У статті окреслено загальні тендениії розвитку клерикальної літератури раннього Середньовіччя. Особливу увагу звернено на жанрово-тематичне розмаӥття дидактичних і літургійних творів, агіографії.

Ключові слова: клерикальна література, аскеза, агіографія, літургійні, дидактичні твори. 
В статье рассмотрень общие тенденции развития клерикальной литературы раннего Средневековья. Особенное внимание обращено на жанровотематическое разнообразие дидактических и литургических произведений, $а$ также агиографии.

Ключевые слова: клерикальная литература, аскеза, агиография, литургические, дидактические произведения.

The article deals with common tendencies of the early Middle Ages clerical literature development. Special attention is paid to genre-thematic variety of didactic and liturgical works and also a hagiography as well.

Key words: the clerical literature, an ascesis, a hagiography, liturgical, didactic products.

В епоху раннього Середньовіччя християнська церква стала невід'ємним елементом земного життя, відіграла координуючу роль у суспільстві. Християнство поступово формалізувалося, набуваючи ознак загальнообов'язкової релігії, що позначилося на сприйнятті людьми церкви, кліру, ієрархії. Священики через сан i його позаособистісну святість поступово відокремлювалися від мирян. Якщо спочатку всі християни вважали себе «долею Божою» серед язичників, то з часом слово «клір» (з грецької «доля») застосовується до стану священнослужителів. Член цього стану мав право молитися за живих і мертвих, звільняти мирян від їхніх гріхів, зціляти, судити, карати та благословляти.

У IV столітті Августин Аврелій розробив аскетичну доктрину, що стала офіційною духовною концепцією Середньовіччя. Згідно з нею людина від народження вже неправедна, тому задля спокутування гріхів і спасіння душі слід бути покірним, відмовитись від земних благ тощо. Аскети вороже ставилися до жінок, вбачаючи в них зброю диявольської спокуси. «Блаженний» Августин закликав мечем і вогнем викорінювати єресь, знищувати віровідступників. Саме таким чином у IV столітті було закладено підвалини інквізиції. «Протиставляючи "язичницьькій" античній філософії новостворювану християнську теологічну систему, Августин у ї̈ філософські підвалини заклав містичний неоплатонізм. У традиціях неоплатонізму онтологія збігалася з теологією. Як хри- 
стиянський теолог Августин підпорядковує земну ієрархію небесній, аргументує переваги теократичної системи, у якій світська влада підпорядкована церковній» [Українська та зарубіжна культура 2003: 97].

Аскеза вимагала повної відмови від власності та постійного перебування в стані духовної молитви. Цей ідеал реалізовано в чернецтві, широкому суспільному феномені, який набув форми притулку для незадоволених формалізацією мирського християнства, забезпечуючи їм місце в рамках ортодоксії.

Ідея чернецтва як усамітнення і зречення земних інтересів не була новою. Ще Платон, Діоген, індійські анахорети, суфії й інші філософи давнини вважали усамітнення та зречення земного проявом вищої мудрості. Однак саме християнство дисциплінувало ці невиразні пориви, створивши інститут чернецтва. Його колискою вважається Сгипет, де в місті Фіваїді навколо святого Антонія об'єдналися відлюдники. Перший статут монастиря в межах західної християнської традиції було написано Бенедиктом (480-543 роки). Заснувавши в 529 році в місцевості Монте-Кассіно, що на півночі Італії, перший у Європі монастир, Бенедикт наголосив на необхідності суворої дисципліни, молитви та зайняття фізичною працею, цілковитої відмови від родини і власності.

Специфічною рисою культури Середньовіччя був еклектизм, що позначився співіснуванням органічно різнорідних світоглядних систем. Перша (репрезентована Магном Флавієм Аврелієм Кассіодором (бл. 480-490 рр.)), об’ єднавши християнську традицію і науку, сприяла становленню світської культури. Друга (доктрина Бенедикта) характеризувалася повним неприйняттям античності, що призвело до духовного диктату церкви. Серед противників застосовування досвіду античності був і папа Григорій I Великий (кін. VI поч. VII ст.), «започатковане яким негативне ставлення до всього язичницького проіснувало до кіния середньовіччя. Григорій I уважав неприйнятною доктрину мирного співіснування різноманітних ідеологій, про щзо свідчать його "Діалоги про життя італійсь- 
ких отців та про безсмертя душі". Така нетерпимість у сфері культури, суттєвим елементом якої є релігія Христа, сприяла зростанню нетерпимості до інакомислячих одновірців, щуо в подальшому стало однією з культурних підвалин інквізиції» [Українська та зарубіжна культура 2003: 98].

У клерикальній літературі раннього середньовіччя християнські традиції домінували над античними. Якщо провідними ідеями античної філософії були заклики змінити життя, звільнити особистість від страждань, здійнятися самій людині над певними обставинами, то соціальна утопія християнства грунтувалася «на надії, що кожний член суспільства зможе і захоче своєю сумирністю і всепрощенням, своєю аскезою спокутувати свої і загальні гріхи. Природно, мистецтво може відвернути людину від цієї мети. За словами Іоанна Златоуста, бідняк, подивившись блискучу виставу, де йому демонструють жіночу красу в оправі всіх аксесуарів заможного і вишуканого життя, роз'ятрює душу і з відразою повертається до свого буття, його дружина здається йому після того особливо бридкою, потворною, його діти - надто галасливими, його дім - убогим. Церква наполягала на тому, що мистецтво має бути морально-виховним, даючи насолоду, воно повинне благотворно впливати на людську душу. Якщо для цього треба відмовитися від певних красивостей, спростити техніку мистецтва - тим краще. До того ж, розруха, яка охопила на переході від античності до середньовіччя весь світ греко-римської цивілізації - варваризований Захід більше, ніж візантійський Схід, мимоволі змушувала спрощувати та економити засоби. Коли Августин у перших книгах трактату "Про місто Боже" таврує видовище, за його нападками стоїть образ пограбованого варварами Риму: «як римські біженці, котрі втратили батьківщину, ще здатні гаяти час і розтринькувати останні кошти на бої гладіаторів» [Культурологія 2006: 129].

Твори клерикальної літератури мали переважно анонімний характер. Серед небагатьох збережених імен творців варто назвати теософа Августина Аврелія, автора трактату «Про град Божий», 
релігійної автобіографії «Сповідь». Клерикальна література була важливим складником у динаміці середньовічного культурного процесу, оскільки відтворювала не тільки офіційні церковні погляди, а й ідеї «єресі», які проникали через низове духовенство.

Твори, у яких розроблено біблійні сюжети, житія святих, легенди, видіння репрезентують літературу традиціоналістського типу, що базувалася на обмеженому наборі образних, ідеологічних, композиційних та інших структур. При розгляді жанрових форм клерикальної літератури передусім необхідно враховувати їх позалітературне, прикладне призначення: панегіричне, моральночи релігійно-сентенційне, декларативне.

Поезія представлена передусім гімнами, головною функцією яких було оздоблення літургії. Відсутність чітких церковних канонів (до XVI століття) обумовила бурхливий розвиток творів цього жанру. Їх писали до свят, на честь святих. Кожна церква, прикрашаючи святкову службу власними вставками, мала можливість інтерпретувати досить вузьке коло образів і мотивів. Обмеженість тематичного діапазону зумовила зосередженість авторів на нюансах, дрібних деталях, що сприяло витонченості творів. Гімни ж, у яких оспівано святих, «різноманітні за змістом та близькі за формою: вступ, епізоди з його діянь, молитва до нього про заступництво, заключне сповідання ортодоксального символу віри» [История всемирной литературы 1984: 503].

Секвенція - досить своєрідний жанр середньовічної лірики. Твори своєю формою швидше нагадують прозу, покладену на музику. Ними супроводжувалося наближення священика до олтаря.

Троп, як і гімн та секвенція, служив вставкою в літургійний текст. Ці твори звучали в зачині дійства, їх виконували з метою емоційного увиразнення дії. Саме «троп був тією ланкою, з якой сформувалася вся новоєвропейська літературна драма» [История всемирной литературы 1984: 504].

До епохи раннього Середньовіччя відноситься зародження літургійної драми, діалогічні тексти якої на цьому етапі складали- 
ся 3 фраз Писання. Поступово вони переходили в сценки, невеликі п’єси на біблійні сюжети, що розігрувалися священиками або півчими біля вівтаря. Кінець ХІ століття засвідчив ідейне й образне збагачення драми. Окрім драматизації біблійних епізодів, розігрувалися житія святих, у показах застосовували декорації (власне театральні елементи). Посилення розважальної та видовищної функції драми, проникнення в неї мирського начала змусило церкву винести ці дійства за межі храму - спочатку на паперть, а потім на міську площу. Літургійна драма стала основою для виникнення середньовічного міського театру. «Щоб не позбавитися послуг театру (не будучи в змозі підкорити його), иерковні власті виводять літургічну драму з-під склепіння храму на паперть. Народжується напівлітургічна драма (середина ХІІ століття). Але тепер уже міська юрба диктує їй свої смаки, змушуючи показувати вистави у дні ярмарків, а не церковних свят, давати побутове тлумачення біблійним сюжетам. Особливо любила публіка сцени з бісами, наділяючи їх рисами середньовічного вільнодумия. У ХІІІ столітті комедійний струмінь у театральному видовищі заглушався театром міраклю, який теж мав своєю темою життєві, але звернені до релігії події. Саме слово "міракль" перекладається з латинської як "чудо". І справді, всі колізії у изьому жанрі завершувалися втручанням божественних сил - св. Миколи, Діви Марії тощчо. Але і в цүі сюжети проникали реальні біди й прикрощі людей через недосконалість життя» [Культурологія 2006: 132].

В алегоричній поезії (як драматичної, так і епічної форми) домінують дидактичні мотиви. У цих творах абстрактні ідеї передано за допомогою образів; світ осмислено як систему відповідностей, де за явищем реальності стоїть релігійний або моральний зміст. Видатними зразками алегорії були «Психомахія» Пруденція, «Антиклавдіан» Алана Лілльського та ін.

Дидактичні тенденції в дусі традиційної християнської етики розвинулися в жанрах зерцала та проповіді. Твори («Перл церковний» Гіральда Камбрійського, «Полікратик» Іоанна Сольсберій- 
ського, «Про любов» Андрія Капеллана та ін.) є своєрідними моральними настановами, у них звучить засудження різного роду розпутств і вад.

Твори, що належали до жанру видіння, також мали повчальний елемент, який основувався на версії, що провидцю відомий шлях праведних та грішних людей у потойбічному житті. У них згідно 3 канонами християнства показано подальший розвиток душі, що залежить від іiі спрямованості перед смертю до добра або зла. Загробний стан людини - це не смерть, це - перехід, продовження духовного життя, що почалося на землі. У видіннях передрікалося, що душам безгрішних воздасться, а в грішників долі різні. Вони теж матимуть певний розвиток: нерозкаяні й великі нечестивці стануть невиправно злими, їх чекає вічне страждання, а інші грішні душі одержать надію на милість Бога й життя вічне. Спільним у загробному світі для цих душ вважалося те, що всі вони ясно й у деталях побачать свої провини на землі. Їх мучитиме совість, котра після смерті стане дуже ясною; бажання, яким поступалася плоть під час земного життя; віддаленість від Бога й близькість до злих духів.

Специфіка цього жанру зумовлена походженням літературного матеріалу, оскільки прийнято вважати, що автору уві сні відкривалася доля людей, картини загробного життя. Часто йшлося про реальних історичних осіб, що сприяло популярності жанру. Мотив пророчого сну реалізувався й у творах більш пізньої доби. Зокрема в «Романі про Троянду», у «Божественній комедії» Данте.

Подібними до видіння були сентенції, запозичені у Святому писанні та в античних поетів-сатириків. Ці твори збиралися у збірки, оригінальні підручники повсякденного досвіду.

На межі літургійних і дидактичних жанрів перебувала агіографія. Це пов'язано з тим, що в житіях святих поєднано дидактичні мотиви та мотиви звеличення праведників, чиє життя демонструвало вищий етичний зразок. У центрі цих творів доброчинність мученика, місіонера або борця за християнську віру. Пафосом 
агіографій є уславлення, які окреслюють ідеал церковного діяча, що обумовило вживання постійних формул похвали непохитного, твердого духу, класичного набору чеснот.

«Поступово жанр житій урізноманітнювався, збагачувався новими деталями (включаючи патріотичний $і$ політичний аспекти), захоплював описами далеких подорожей, подвигів, чудес $i$ навіть гумором. Пізніше виникли легенди. Спочатку легендами називали релігійно-фантастичні біографії святих; з часом пов'язані з релігійним культом притчі про тварин, рослини тощо. Наприклад, притчі про лева, який безжалісно мордував язичників, але віддано служив християнам-пустельникам. Із середини XII століття з'являсться велика кількість народних легенд про Богоматір, в яких розповідається про любов і співчуття Мадонни до простих людей» [Рубанова 1982: 37]. Популярними були легенди про Діву Марію та жонглера, святого Франциска Ассизького (кінець XII століття), що заснував орден францисканців та ін. Широкого розповсюдження в середньовічній Свропі отримала «Золота легенда» Якова Ворагинського (XIII століття) - зведення житій католицьких святих.

Життя простолюдина цієї доби обмежувалося заповідями християнської літургії, що збагачувала особу високими духовними ідеями. Позарелігійні замисли карнавальної, сміхової стихії надавали певних свобод. Поведінка людей під час карнавалу не коригувалася нормами моралі й етикету, ієрархічними відносинами. Прагнучи вивільнитися від стереотипних ритуалів, вони пародіювали різноманітні церемонії. «У сміховій латинській літературі є пародійні куплети буквально на всі моменти церковного культу та віровчення навіть на молитви і проповіді, а також пародійні заповіти ("Заповіт свині", "Заповіт осла") й епітафії, пародійні постанови соборів, пародійні лицарські романси» [Культурологія 2006: 132].

Отже, ідеї християнства в епоху раннього Середньовіччя знайшли своє вираження в клерикальних творах різних жанрів. Переважно вони представлені літургійними творами, розрахованими 
на ритуальне вживання в межах християнської громади (гімни, секвенції, тропи, літургійна драма тощо) та дидактичними творами, що мають релігійно-повчальний зміст (алегоричні поезії, зерцала, видіння та ін.). Особливості їх поетикальної організації полягають у застосуванні постійних епітетів, образотворчих кліше, стійкості мотивів, незмінності канонів для зображення системи образів (християнського мученика чи лицаря, імператора чи городянина і т. д.).

\section{БІБЛІОГРАФІЯ}

История всемирной литературы 1984 - История всемирной литературы : в 9 т. / АН СССР ; Ин-т мировой лит. им. А. М. Горького. - М. : Наука, 1983-1994. Т. 2 : Раннее и Зрелое Средневековье, II-III вв. н. э. XIII - нач. XIV в. / редкол. Г. П. Бердников (гл. ред.) и др. - М. : Наука, 1984. -672 с. - Имен. указ. : С. 622-632. - Указ. произвед. : С. 633-644. - Синхронистич. табл. : С. 647669. - Библиогр. : С. 597-621.

Культурологія 2006 - Культурологія: українська та зарубіжна культура: навч. пос. / М. М. Закович, І. А. Зязюн, О. М. Семашко, Ж. О. Безвершук ; за ред. М. М. Заковича. -3 вид. - К. : Знання, 2006. -567 с. - (Вища освіта XXI століття).

Рубанова 1982 - Рубанова Г. Л. Історія зарубіжної літератури: Середні віки та Відродження / Г. Л. Рубанова, В. А. Моторний. - Львів : Вища школа, 1982. - 440 с. Українська та зарубіжна культура 2003 - Українська та зарубіжна культура : навч.-метод. пос. для самостійного вивчення дисципліни / Р. М. Вечірко, О. М. Семашко, В. В. Олефіренко та ін. - К. : КНЕУ, 2003. - 367 с. 